Chapman University

Chapman University Digital Commons

Communication Faculty Articles and Research

School of Communication

$11-2-2015$

\title{
Exploring the Role of Identification and Moral Disengagement in the Enjoyment of an Antihero Television Series
}

Sophie Janicke

Chapman University, janicke@chapman.edu

Arthur A. Raney

Florida State University

Follow this and additional works at: http://digitalcommons.chapman.edu/comm_articles

Part of the Communication Technology and New Media Commons, Critical and Cultural

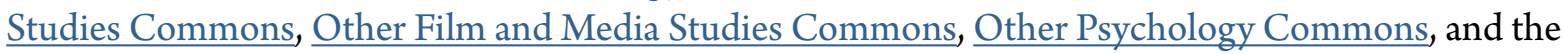
Television Commons

\section{Recommended Citation}

Janicke, S. H., \& Raney, A., A. (2015). Exploring the role of identification and moral disengagement in the enjoyment of an antihero television series. Communications: The European Journal of Communication Research, 40(4), 485-495. doi 10.1515/commun-2015-0022

This Article is brought to you for free and open access by the School of Communication at Chapman University Digital Commons. It has been accepted for inclusion in Communication Faculty Articles and Research by an authorized administrator of Chapman University Digital Commons. For more information, please contact laughtin@chapman.edu. 


\section{Exploring the Role of Identification and Moral Disengagement in the Enjoyment of an Antihero Television Series}

\section{Comments}

This article was originally published in Communications: The European Journal of Communication Research, volume 40, issue 4, in 2015. DOI: 10.1515 / commun-2015-0022

\section{Copyright}

De Gruyter Mouton 


\section{Research in brief}

Sophie H. Janicke* and Arthur A. Raney

Exploring the role of identification and moral disengagement in the enjoyment of an antihero television series

DOI 10.1515/commun-2015-0022

Abstract: Affective disposition theory explains well the process of enjoying hero narratives but not the appeal of narratives featuring antiheroes. Recent antihero studies suggest that character identification and moral disengagement might be important factors in the enjoyment of such fare. The current study builds on this work. A sample of 101 self-identified fans and nonfans of the television series 24 viewed a condensed version of Season 1, providing evaluation of various protagonist perceptions, moral judgments, and emotional responses to the narrative, as well as overall enjoyment. As expected, fans reported greater liking of the protagonist and greater enjoyment. But more importantly, regression analyses illuminated key differences between the groups in terms of the factors predicting enjoyment, providing a clearer picture of how we enjoy antihero narratives.

Keywords: enjoyment, antihero, affective disposition theory, identification, moral disengagement

\section{Introduction}

Entertainment psychologists have recently turned a scholarly eye on the appeal and enjoyment of so-called antihero narratives, those increasingly popular stories featuring protagonists whose conduct is at best morally ambiguous, questionable, and at times unjustifiable. For the past four decades, affective disposition theory (ADT) (Zillmann and Cantor 1976) has guided investigations into

*Corresponding Author: Sophie H. Janicke, University of Arkansas (USA), Department of Communication, E-mail: sophie.janicke@gmail.com

Arthur A. Raney, Florida State University (USA), School of Communication, E-mail: araney@fsu.edu 
the media-enjoyment process. However, ADT suggests that positive moral evaluations of the protagonist's behaviors and motivations are central to enjoyment. Such evaluations seem inappropriate with morally complex antiheroes. Thus, the purpose of the current study is to explore the process by which antihero characters are perceived and enjoyed. To that end, self-identified fans and nonfans of the once-popular U.S. television series 24 - in many ways, a prototypical antihero story - were studied to examine the factors (especially identification and moral disengagement) predicting enjoyment for both groups.

As noted above, ADT has been a leading theory in examining the process of narrative enjoyment. One expression of ADT is the moral sanction theory of delight and repugnance (Zillmann 2000), which highlights the interdependence of affective disposition and moral judgments responsible for the enjoyment experience. These ideas were further explored and developed in the integrated model of enjoyment offered by Raney and Bryant (2002). Both models argue that a viewer's emotional reactions toward media characters' behaviors, motivations, and emotional responses are a function of affective and moral judgmental processes. With the typical hero narratives, protagonists are loved more as their behaviors and motivations are judged to be morally right and good, while villains are despised relative to how immoral and evil their works are judged to be (e.g., Zillmann 2000; Zillmann and Bryant 1975). The intensity of the dispositions formed toward these characters, in conjunction with the outcomes they experience, leads to enjoyment.

The ADT formula described here has been met with strong empirical support (see Raney 2006 for a summary). But practically all of this work has investigated the theory using traditional hero narratives. Why might we expect any differences with antihero stories? Because, according to the theory, moral considerations are the basis for disposition formation. From a strict ADT perspective: If a protagonist is repeatedly willing to take a moral short cut to solve a problem or is overly vicious in rendering punishment, then it follows that a viewer would find it difficult to interpret such actions as moral. Consequently, the protagonist should not be liked. But clearly viewers love antiheroes: Tony Soprano in The Sopranos, Lisbeth Salander in The Girl with the Dragon Tattoo, Michael Corleone in The Godfather, Dexter Morgan in Dexter, and, for our purposes, 24's Jack Bauer.

Several recent studies have agreed upon a possible explanation for the enjoyment of antiheroes: The process of moral disengagement may well help viewers overcome the cognitive distress that should theoretically arise from liking a morally questionable character (cf., Krakowiak and Tsay 2011; Krakowiak and Tsay-Vogel 2013; Raney, Schmid, Niemann, and Ellensohn 2009; Tsay and Krakowiak 2011). Bandura (1991) described moral disengagement as the 
process by which we alleviate cognitive and affective discomfort experienced when we or someone we like violates our moral standards. "By reconstructing conduct, obscuring causal agency, disregarding or misinterpreting injurious consequences, and blaming and devaluating the victims” (Bandura 1991, p. 67), the usual moral control we exert over our own thoughts and behaviors can be deactivated without guilt, allowing us to behave in morally questionable ways or give amnesty to others who do. Raney $(2004,2006)$ argued that the same should hold true for our narrative friends as well. The goal of enjoyment is so important for us as viewers that we interpret the morally improper behaviors of liked characters as proper in order to maintain our positive dispositions, and thus improve our chances of enjoying narratives. Instead of morally scrutinizing the actual behaviors - as ADT suggests - viewers likely extend their latitudes of moral sanction to justify a character's behavior, thus maintaining the positive disposition necessary for enjoyment. For example, Krakowiak and Tsay (2011) found that character liking mediates the relationship between moral disengagement and enjoyment of an antihero narrative. Raney and colleagues (2009) found that a protagonist in an antihero-framed clip was liked more than one in a hero-framed clip, with viewers reporting more enjoyment of the antihero-framed clip. Further, they reported that character identification with the antihero protagonist, rather than moral judgment of the character's behavior, predicted enjoyment. Finally, Tsay and Krakowiak (2011) found that identification and perceived similarity with a morally ambiguous character - factors not appearing in the basic ADT formula - increased the tendency for viewers to justify such character's actions. In fact, Raney and Janicke (2013) argued that identification is foundational to the liking of an antihero in ways that moral approval of the character's actions is not. Janicke and Raney (2012) found support for this claim.

Furthermore, from a more general perspective, Raney (2004; see also Raney and Janicke 2013) challenged the traditional ADT assumption that viewers like or dislike characters because of their moral evaluation of a character's behavior. He argued that evaluations of a character's goodness might actually reflect post hoc justification of (or a priori assumptions about) those behaviors. Through repeated experiences with entertainment media, its story lines and character descriptions, viewers develop story schema knowledge (cf. Mandler 1984) that helps them to automatically classify characters as 'bad' and 'good'. Such classification leads viewers to anticipate or interpret character behaviors to be either morally proper or improper; thus, protagonists are judged to be moral because they are protagonists. And protagonists by definition should be moral and liked (see Janicke [2014] for a more detailed discussion of schema theory as applied to antihero narratives). With serial television, it would seem that repeated expo- 
sure to the same protagonist could lead to such a justified (rather than justifiable) disposition.

In sum, the scholarly record in media psychology examining antihero narratives is still in its infancy. The current study adds to this growing area by further investigating some of the variables emerging in these initial studies particularly moral judgment/disengagement and identification - with Raney's schema argument as a theoretical foundation. To do so, we compared fans and nonfans of the television series 24. To date, a comparison based on fanship or repeated exposure has not been reported. Given what is generally seen as a steady increase in antihero television shows, it would seem that such a study is timely, practical, and relevant.

Based on Raney's schema argument, one could conclude that fans might develop certain schemas about characters in serial television, making it more likely for them to prejudicially justify, rather than continually evaluate, character actions. As a result, liking should increase. In contrast, nonfans or viewers watching a certain program the first time will not have developed these character schemas. It would then follow that nonfans should be less able or willing to disengage from the morally questionable actions of an antihero, resulting in less protagonist liking and little (or, at least, less in comparison to fans) enjoyment. Thus, we predicted:

[H1] After watching a summary clip, fans of 24 will report greater liking of the antihero protagonist than nonfans. And:

[H2] After watching a summary clip, fans of 24 will report greater enjoyment than nonfans.

We acknowledge that these predictions simply seek to verify what most would think is common sense. But in the current study, support would confirm the presumed fan-nonfan differences for the purpose of then exploring the factors affecting why such differences might emerge, with the hope of further illuminating how people enjoy antihero narratives. Thus, the primary analyses of our project interrogate the following research question:

[RQ1] How do character perception, identification, moral judgment of behaviors, empathic reactions, and perceptions of outcome deservedness differentially influence the summary clip enjoyment of fans and nonfans?

The selection of these specific predictor variables is theoretically grounded in Raney and Bryant's (2002) integrated model of enjoyment, and empirically sup- 
ported by previous studies by Weber, Tamborini, Lee, and Stipp (2008) and Raney and colleagues (2009). Investigating fans and nonfans of serial TV dramas provides us with the opportunity to elucidate the underlying processes of a viewer's willingness (or rather automaticity) to accept immoral actions of beloved protagonists based on the viewer's previously developed schemas.

\section{Methods}

One hundred and one individuals participated in the study in exchange for course or extra credit. Forty participants reported viewing 24 at least once per month; these constituted the fan condition, with the remaining 61 treated as nonfans. This distinction was further verified before viewing. Participants answered five multiple-choice questions testing basic information about the series. Self-identified fans on average answered 4.08 questions correctly ( $S D=$ 1.16); nonfans answered only 2.26 questions correctly $(S D=1.12)$. Thus, nonfans had much less familiarity with, and knowledge of, the show than fans.

Before viewing, participants completed an IRB-approved consent form and a questionnaire containing demographic and media-use items, as well as the five series-knowledge questions. The questionnaire also included attitudinal measures common to ADT studies (e.g., trait empathy, social justice attitudes such as vigilantism and punitiveness). While these scales were not utilized in our primary analyses, they allowed us to compare the groups on attitudes relevant to the study. As expected, no statistically significant differences $(p>.05)$ were observed between fans and nonfans on these stable attitudinal measures; therefore, we contend that the groups differed primarily in terms of 24 viewing.

The participants then viewed a 42-minute summary of the first season of the TV crime series 24, released in 2001. The summary introduced the major characters, presented the major crimes against the U.S. government and the protagonist Jack Bauer's family, and provided the final punishment for the villains. It highlighted several morally questionable actions carried out by Bauer to protect the country's security, while also protecting the lives of his family members. In the final scene, Bauer shoots the main villain (who Bauer thinks has killed his daughter, although she is actually alive). Viewers are forced to decide if this punishment was appropriate, with the outcome of such judgments surely impacting enjoyment, per the ADT formula.

At the end of the video clip, a second questionnaire was administered. A five-point Likert-type scale previously used by Raney and his colleagues (2009) was adapted to measure viewer perceptions of the protagonist. Four items 
measured perceived character attractiveness (e.g., social, funny: $\alpha=.75$ ), while another four items measured perceived character morality (e.g., bad, selfish [reverse coded]: $\alpha=.70$ ). A four-item scale based on previous research assessed the degree to which the viewer identified with the protagonists (e.g., "I can put myself in Jack Bauer's position very well”, from Cohen [2001]). After deletion of one item, the internal consistency was deemed somewhat weak $(\alpha=.55)$ but acceptable given the importance of the factor in previous antihero studies. The resulting three-item, five-point Likert-type scale measured identification with the protagonist.

Six items were used as an indirect measurement of moral disengagement (e.g., "I think Jack Bauer behaved morally correctly"), capturing a viewer's post hoc moral evaluation of the protagonist's behavior (Raney et al. 2009). Participants rated the moral disengagement items on a five-point Likert scale $(\alpha=$ .81). Theoretically speaking, a positive correlation between this scale and the enjoyment measure (described below) would mimic the traditional ADT formula: "The protagonist was moral, and I enjoyed it" or "The protagonist was immoral, and I didn't enjoy it”. Such a correlation would not seemingly fit an antihero narrative (especially for fans). But, if the moral disengagement scale and enjoyment were found to be negatively related, then this would seemingly indicate that Bauer's immorality had no detrimental effects on enjoyment: "The protagonist was immoral, and I enjoyed it." We would take this as evidence that the viewers morally disengaged for the sake of enjoyment (see Raney 2004).

Two measures of empathic reaction to the narrative were observed, both taken from previous ADT studies (Raney 2002, 2005). Four items, using an 11point Likert-type scale, measured empathic concern for the protagonist (e.g., "How much did you like the victim?"; $\alpha=.79$ ). Also, we adapted three of the protagonist-sympathy items to gauge empathic reactions toward the villain (i.e., "How sorry did you feel towards [the villain]?”; $\alpha=.67)$. In some ways, this scale serves as a control measure for protagonist sympathy, expecting low values if protagonist sympathy is high. Also, previous ADT research (Raney 2002, 2005) used a single, 11-point item to measure the extent to which the villain's punishment meets with what was deserved. We used the same item. Finally, enjoyment of the summary clip was tested with eight items previously reported from Raney (2002) and Raney and Bryant (2002). All items were rated on an 11-point Likert scale $(\alpha=.93)$.

\section{Results}

A series of one-way ANOVA procedures were used to evaluate the two hypotheses (see Table 1). First, as expected, fans reported greater liking of the protago- 
Table 1: Means, standard deviations, and significance-test values for hypotheses 1 and 2.

\begin{tabular}{|c|c|c|c|c|c|c|}
\hline & \multicolumn{2}{|l|}{ Fan } & \multicolumn{2}{|c|}{ Nonfan } & \multirow[t]{2}{*}{ Welch* } & \multirow[t]{2}{*}{$p$} \\
\hline & $M$ & $S D$ & $M$ & $S D$ & & \\
\hline Character identification & 3.21 & 0.67 & 2.78 & 0.87 & 7.75 & .006 \\
\hline Protagonist sympathy & 7.74 & 1.31 & 7.12 & 1.79 & 3.16 & .079 \\
\hline Enjoyment & 8.00 & 1.22 & 5.85 & 2.29 & 29.89 & .001 \\
\hline
\end{tabular}

Note: *Homogeneity of variance assumptions were violated; therefore, Welch values were used.

nist Jack Bauer than nonfans. This difference is indicated by significantly higher scores for fans on the character identification factor, as well as (marginally so) on the protagonist sympathy factor. Therefore, Hypothesis 1 was supported. Likewise, fans reported significantly greater enjoyment of the summary clip than nonfans. Hypothesis 2 was supported.

As noted, these initial hypotheses simply confirm what most would call common sense, but empirical verification of such was necessary at the outset. Now, we can turn our attention to the more important job of exploring the factors affecting why such differences exist. A set of multiple regression procedures examined the predictive power of several variables identified in previous studies on enjoyment (see Table 2). Past antihero and ADT scholarship suggested that differences - though not fully explained or understood - should exist between fans and nonfans in terms of the constellations of variables predicting enjoyment. Specifically, we examined the role of three protagonist evaluations (perceived attractiveness, perceived morality, identification), two moral judgments (moral judgment of protagonist behaviors, perceived deservedness), and two measures of empathic reaction (protagonist sympathy, villain sympathy) in the enjoyment process of each condition.

In the nonfan condition, the model proved significant: $F_{7,53}=3.99, p<.005$, with $34.5 \%$ of the variance explained. Two protagonist-related factors emerged as significantly strong predictors of enjoyment: perceived character attractiveness and character identification.

A somewhat different picture emerged in the fan condition. A significant model was again observed: $F_{7,32}=4.19, p<.001$, with $47.8 \%$ of the variance explained. Perceived character attractiveness was again a strong predictor of enjoyment. However, this relationship was negative for fans. A similar (though non-significant) pattern was found with the perceived character morality factor. Despite this odd-seeming pattern, we observed that protagonist sympathy was the strongest (positive) predictor of fan enjoyment. Thus, despite these appar- 
Table 2: Multiple regression analysis with all character evaluation measures and enjoyment.

\begin{tabular}{|c|c|c|c|c|c|c|}
\hline & \multicolumn{3}{|l|}{ Fans* } & \multicolumn{3}{|c|}{ Nonfans** } \\
\hline & B & $\beta$ & $p$ & B & $\beta$ & $p$ \\
\hline $\begin{array}{l}\text { Perceived character } \\
\text { attractiveness }\end{array}$ & -.696 & -.417 & .004 & .825 & .287 & .023 \\
\hline Perceived character morality & -.366 & -.211 & .175 & -.210 & -.063 & .639 \\
\hline Character identification & .392 & .214 & .149 & .886 & .337 & .007 \\
\hline Moral judgment of behavior & -.666 & -.394 & .014 & -.750 & -.212 & .116 \\
\hline Protagonist sympathy & .612 & .605 & .000 & .077 & .052 & .708 \\
\hline Villain sympathy & -.038 & -.042 & .802 & -.300 & -.173 & .184 \\
\hline Outcome deservedness & .085 & .170 & .224 & .104 & .119 & .323 \\
\hline
\end{tabular}

Note: ${ }^{\star} F_{7,32}=4.19, p<.001 ; R^{2}=.478 ;$ Adjusted $R^{2}=.364 ;{ }^{\star \star} F_{7,53}=3.99, p<.002$; $R^{2}=.345 ;$ Adjusted $R^{2}=.258$

ent tacit acknowledgements that the character is unattractive and immoral, still greater empathic concern for him was associated with increased enjoyment. This perhaps makes the most sense in conjunction with the fact that the moral judgment of the protagonist's behavior was also a significant, negative predictor of enjoyment. As discussed earlier, this pattern of findings (i.e., negative relationship between moral judgment of behavior and enjoyment) can reasonably be interpreted as moral disengagement for the sake of enjoyment.

\section{Discussion}

This study explored the process by which antihero characters are perceived and enjoyed. Fans and nonfans of the television series 24 viewed a condensed version of Season 1 of the series. As expected, fans liked the protagonist (Jack Bauer) and enjoyed the clip more than nonfans. Of greater interest were the factors that might predict enjoyment in each group. ADT and previous antihero studies offered several factors to examine. With the group of nonfans, we found that character attractiveness and identification significantly predicted enjoyment. These findings are consistent with the emerging picture of antihero reception and reflect the spirit of the ADT formula for enjoyment.

As noted above, ADT predicts that enjoyment increases the more we like the characters who win out. Good triumphing over evil is a key ingredient to the recipe for enjoyable (traditional) narratives. In our study, nonfans - those without 24-related schemas to help interpret the story - apparently viewed the 
narrative through the lens of a typical hero narrative. Or at least, enjoyment increased in relation to a nonfan . Enjoyment for nonfans increased as protagonist attraction increased. Traditional hero narratives require a force of good, someone who is attractive and liked. Nonfans apparently interpreted the narrative with this expectation in mind.

How were they able to do so? Identification appears to be the mechanism enabling this. Both Tsay and Krakowiak (2011) and Raney and colleagues (2009) reported the importance of identification in the enjoyment of antihero narratives, with the latter noting the marked absence of moral judgment as a predictor of enjoyment (also found here). If viewers are not relying on moral judgment to develop an affiliation with antiheroes but still experience great liking, then their enjoyment is being derived in ways other than morally. Identification and perceived attractiveness seem to be two of those ways.

This is quite a different process than the one observed with the fans. Previous exposure to the series should lead to more complex dispositions toward the protagonist. As we argued above, it is precisely these highly developed dispositions that should lead to moral disengagement for the sake of enjoyment. Fans should overlook negative qualities to ensure increased liking and enjoyment. The findings from the regression analysis support this logic.

For fans, character attractiveness was an unsurprisingly strong predictor of enjoyment. Surprisingly, though, the relationship was negative. Thus, the less attractive the fans found Bauer, the more they enjoyed the clip. The same pattern was found for the moral judgments of Bauer's behaviors (and for the character morality factor, though not significant). The more the fans found Jack Bauer's actions to be immoral, the more they enjoyed the clip.

Despite these two strong findings, enjoyment for the fans was best predicted by sympathy for the protagonist. This finding is in line with the ADT literature. The difference with the antihero narrative, though, seems to be the route taken to experiencing that sympathy. In previous research, positive evaluations of characters and their behavior led to more sympathy (with enjoyment also increasing). In the case of 24 , fans know that Jack Bauer is unlikeable, unattractive, and acts immorally. But this does not matter. In fact, for fans, the more that this is thought to be the case, the more enjoyment follows. Such a pattern is consistent with the previous claims about moral disengagement as a strategy for the sake of enjoyment. Further, the results in the nonfan condition only corroborate this claim, with neither character attractiveness nor moral judgments negatively predicting enjoyment in this way. Thus, it seems that nonfans did not disengage the immoral behavior of Jack Bauer like the fans; this likely explains in part the differences in enjoyment. 
Further, although character identification does not emerge as a statistically significant predictor of enjoyment with the fans, we still argue that it may be the mechanism through which moral disengagement for the sake of enjoying antihero narratives operates. Janicke and Raney (2012) report support for this proposition. We think identification is the necessary component that allows the negative valences associated with the perceived attractiveness and moral judgment factors to coexist with the high sympathy ratings; identification makes moral disengagement possible (cf. Raney and Janicke 2013). Further, identification with Jack Bauer is not inconsequential for fans. As the reader will recall, fans identified with the protagonist significantly more than the nonfans (see Table 1).

Thus, in contrast to traditional hero narratives, identification with, and sympathy for, antiheroes made possible through moral disengagement are key ingredients for the enjoyment of narratives containing such protagonists. We acknowledge we are still a bit limited in our ability to state this irrefutably. Our study (similar to those before us) used a single stimulus material; we realize that content-specific features may lead to unique results. Therefore, we encourage additional studies to validate these findings. However, given the consistency of our results with other similar studies, we think that the picture of antihero enjoyment is becoming clearer. As media psychologists, our understanding of antihero narratives is relatively limited. But their popularity across the media landscape is on the rise. We would be remiss if we did not continue to seek better insight into these socially significant media experiences.

\section{References}

Bandura, A. 1991. Social cognitive theory of moral thought and action. In W. M. Kurtines \& J. L. Gewirtz (Eds.), Handbook of moral behavior and development: Theory, research and applications (Vol. 1, pp. 45-129). Hillsdale, NJ: Erlbaum.

Cohen, J. 2001. Defining identification: A theoretical look at identification of audiences with media characters. Mass Communication \& Society, 4, 245-264. doi:10.1207/ S15327825MCS0403_01.

Janicke, S. H. 2014. Moral schemas in crime dramas: The matter of context for the activation of an antihero schema and its impact on moral judgment making [Doctoral dissertation]. Retrieved August 4, 2015 from ProQuest, http://search.proquest.com/ docview/1506973153.

Janicke, S. H., \& Raney, A. A. 2012. Modeling the antihero narrative enjoyment process. Paper presented at the annual meeting of the International Communication Association, Pheonix, AR, May 2012.

Krakowiak, K. M., \& Tsay, M. 2011. The role of moral disengagement in the enjoyment of real and fictional characters. International Journal of Arts and Technology, 4, 90-101. doi:10.1504/IJART.2011.037772. 
Krakowiak, K., \& Tsay-Vogel, M. 2013. What makes characters' bad behaviors acceptable? The effects of character motivation and outcome on perceptions, character liking, and moral disengagement. Mass Communication \& Society, 16, 179-199. doi:10.1080/ 15205436.2012.690926.

Mandler, J. M. 1984. Stories, scripts, and scenes: Aspects of schema theory. Hillsdale, N): Erlbaum.

Raney, A. A. 2002. Moral judgment as a predictor of enjoyment of crime drama. Media Psychology, 4, 307-324. doi:10.1207/S1532785XMEP0404_01.

Raney, A. A. 2004. Expanding disposition theory: Reconsidering character liking, moral evaluations, and enjoyment. Communication Theory, 14, 348-369. doi:10.1111/j.14682885.2004.tb00319.x.

Raney, A. A. 2005. Punishing media criminals and moral judgment: The impact on enjoyment. Media Psychology, 7, 145-163. doi:10.1207/S1532785XMEP0702_2.

Raney, A. A. 2006. The psychology of disposition-based theories of media enjoyment. In J. Bryant \& P. Vorderer (Eds.), Psychology of entertainment (pp. 137-150). Mahwah, N): Erlbaum.

Raney, A. A., \& Bryant, J. 2002. Moral judgment and crime drama: An integrated theory of enjoyment. Journal of Communication, 52, 402-415. doi:10.1111/j.14602466.2002.tb02552.x.

Raney, A. A., \& Janicke, S. 2013. How we enjoy and why we seek out morally complex characters in media entertainment. In R. Tamborini (Ed.), Media and the moral mind (pp. 152-169). London: Routledge.

Raney, A. A., Schmid, H., Niemann, J., \& Ellensohn, M. 2009. Testing affective disposition theory: A comparison of the enjoyment of hero and antihero narratives. Paper presented at the annual meeting of the International Communication Association, Chicago, IL, May 2009. Retrieved April 14, 2014 from http://citation.allacademic.com/ meta/p_mla_apa_research_citation/3/0/0/1/7/p300171_index.html.

Tsay, M., \& Krakowiak, K. M. 2011. The impact of perceived character similarity and identification on moral disengagement. International Journal of Arts and Technology, 4, 102-110. doi:10.1504/IJART.2011.037773

Weber, R., Tamborini, R., Lee, H., \& Stipp, H. 2008. Soap opera enjoyment: A longitudinal test of disposition theory. Media Psychology, 11, 462-487.

Zillmann, D. 2000. Basal morality in drama appreciation. In I. Bondebjerg (Ed.), Moving images, culture and the mind (pp. 53-63). Luton: Luton University Press.

Zillmann, D., \& Bryant, J. 1975. Viewer's moral sanction of retribution in the appreciation of dramatic presentations. Journal of Experimental Social Psychology, 11, 572-582.

Zillmann, D., \& Cantor, J. 1976. A disposition theory of humor and mirth. In A. J. Chapman \& H. C. Foot (Eds.), Humor and laughter: Theory, research and applications (pp. 93-115). London: John Wiley \& Sons. 